\section{The genetic background of resistance to common bacterial blight in newly identified common bean lines on the basis of inheritance studies}

\author{
Mergenthaler E. ${ }^{1}$ and Bisztray Gy. ${ }^{2}$
}

INTERNATIONAL

JOURNAL OF

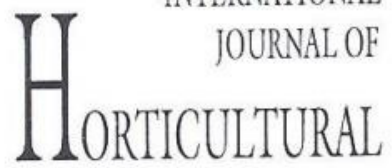
SCIENCE

AGROINFORM

Publishing House, Hungary

IPlant Protection Institute, Hungarian Academy of Sciences, 1525 Budapest, P.O. Box 102, Hungary

${ }^{2}$ Szent István University, Faculty of Horticulture, Dep. of Genetics and Plant Breeding, 1502 Budapest, P.O. Box 53., Hungary

Key words: Phaseolus bean, Xanthomonas, resistance, inheritance

Summary: Common bacterial blight (CBB), caused by Xanthomonas campestris pv. phaseoli $(\mathrm{Xcp})$. is a major disease problem of common bean (Phaseolus vulgaris L.). The inheritance of resistance in Xr1 and Xr2 lines to two isolates of Xcp was studied in the F2 and F3 populations from the crosses between these lines and the Masay variety (susceptible to Xcp). Segregation patterns indicated that different single recessive genes presumably in coupling phase linkage determined the resistance to the HUN and EK-11 strains of Xcp in both lines. The presence of some minor, modifying genes beside the monogenic genetic background of resistance was also observed. Xrl and Xr2 lines represent valuable new monogenic genetic sources in resistance breeding to CBB.

\section{Introduction}

One of the most important diseases of common bean (Phaseolus vulgaris L.) is common bacterial blight (CBB), incited by Xanthomonas campestris pv. phaseoli (Smith) Dye $(X c p)$. CBB causes economic losses in bean producing regions worldwide, due to a reduction in seed yield and seed quality (Yoshii, 1980; Saettler, 1989). Investigations in the $1970-\mathrm{s}$ and 1980-s generally proved that the pathogen Xanthomonas campestris pv. phaseoli is one of the most common stressor on bean in Hungary as well (Velich et al., 1994). Effective and ecological control for this disease seems most likely to be achieved through breeding resistant or tolerant cultivars (Sanders \& Schwarz, 1980).

Resistance to CBB in beans may be determined by both major and minor, modifying genes. The reaction to the pathogen was found to be quantitatively inherited (Coyne and Schuster, 1974; McElroy et al., 1985; Velich et al., 1991). This horizontal resistance is poligenically inherited, and exhibits a nonrace-specific reaction to various races or strains (Opio et al., 1996), however host genotype x bacterial strain interactions have been reported by several authors (Aggour et al., 1989; Arnaud-Santana et al., 1993). Generally low to moderate heritabilities of the reactions to $X_{c p}$ were found in different plant organs (Ariyarathne, 1994; Arnaud-Santana et al., 1994). The number of genes affecting resistance to $X c p$ found in several crosses were different, depending on the source of resistance (Coyne and Schuster, 1974; Eskridge \& Coyne, 1996; Musaana et al., 1993; Silva et al., 1989). Transgressive segregation for higher levels of resistance to the $X c p$ pathogen was observed also in bean
(Valladares-Sanchez et al., 1979). Differential leaf and pod resistance to Xcp (Aggour et al., 1989; Mubaga et al., 1991) have been reported, unlike to others who observed intermediate association for bean leaf and pod reaction (Rava et al., 1987; Arnaud-Santana et al., 1994). Germplasm with CBB resistance has been identified in P. vulgaris, and bean varieties and lines resistant or partially resistant to $X c p$ have been developed (Coyne \& Schuster, 1969, 1974, 1983; Yoshii et al, 1978; Saettler, 1989). However, despite of extensive research on the development of $\mathrm{CBB}$ resistant varieties, high levels of resistance have not been achieved. The lack of high levels of $\mathrm{CBB}$ resistance in $\mathrm{P}$. vulgaris germplasm encourages the process to screen Phaseolus species for resistance and to do research on interspecific hybridization.

The highest levels of $\mathrm{CBB}$ resistance have been reported in tepary bean, Phaseolus acutifolius (Honma, 1956; Schuster et al., 1983; Drijfhout \& Blok, 1987). The genom of $P$. acutifolius is a valuable source for improving the level of resistance found in $P$. vulgaris germplasm. Several workers transferred genes from $P$. acutifolius into susceptible $P$. vulgaris, creating a range of bean genotypes with resistance to CBB, such as GN Nebraska \#1 Sel. 27 (Coyne \& Schuster, 1983), XAN lines (Mc Elroy, 1985), and navy bean lines (Scott and Michaels, 1992). Xcp resistance gene effects are predominantly additive (Valladeres et al., 1979; Silva et al., 1989), with dominance or partial dominance sometimes occurring (Scott \& Michaels, 1988). Although a dominant major gene were reported to primarily determine the reactions to Xcp in tepary beans (Drijfhout \& Blok, 1987) and major genes have been tagged in interspecific crosses 
(Park et al., 1998), McElroy (1985) and later Freytag (1989) reported a quantitative pattern of inheritance of resistance in an interspecific cross with three genes involved in controlling resistance to $X c p$. Accordingly, despite the original qualitative, race-specific resistance of $P$. acutifolius to different isolates of the CBB pathogen (Zapate \& Vidaver, 1987; Zaiter et al., 1989; Dursun et al., 1994), the resistance of hybrids remained in most cases race-nonspecific in common bean backgrounds (Opio et al., 1996).

An intensive genetic program for bean improvement has been started in the eighties in Hungary. Resistance breeding and genetic research aimed at developing resistance to the most important diseases of hungarian bean production, halo blight (incited by Pseudomonas syringae pv. phaseolicola) and common bacterial blight. To expand the range of resistance sources 1500 varieties and lines were tested, however a great part of foreign varieties carrying resistance to $X c p$ were susceptible to the aggressive isolates in Hungary. Previous experiments based on a 9 parent diallel trial proved also the polygenic regulation of foliage resistance to Xcp (Velich et al., 1991). Recently some presumable new, monogenic resistance sources for CBB has been identified in the germplasm of Hungary (Szarka, 1993), namely the $\mathrm{Xr} 1$ and $\mathrm{Xr} 2$ lines. Experiments with $\mathrm{Xr} 1, \mathrm{Xr} 2$ along with the american Walley line suggested the presence of dominant allele(s), and similar genetic background of resistance to $X c p$. In diallel populations the number of blocks taking part in resistance to $X c p$ were estimated to be 1.8 (F1) and 1.3 (F2), affirming the hypothesis of a single major gene system for $\mathrm{CBB}$ resistance affected by modifying genes (Velich et al., 1994). The origin of these lines is unknown, only one isozyme study, including european varieties, representatives from the andean and mesoamerican gene pool, a P. acutifolius line and two interspecific hybrids contributed to the identification of the genetic background of $\mathrm{Xr} 1, \mathrm{Xr} 2$ lines. Most isozyme patterns showed relatedness with european varieties, however relationship with P. acutifolius could be observed in two cases as well (Békefi, 1997). The objective of this study was to further investigate the genetic basis of resistance to $X c p$ of $\mathrm{Xr} 1$ and $\mathrm{Xr} 2$ lines, by making a new cross with a european susceptible variety (Masay), and testing an american Xanthomonas isolate (EK-11) along with the hungarian. Long-term goals are to tag and map disease resistance gene(s) of both lines controlling resistance to $X c p$.

\section{Materials and methods}

\section{Plant material}

Inheritance studies were performed on F2 and F3 progeny of crosses between $\mathrm{Xr} 1, \mathrm{Xr} 2$ lines resistant to $X_{c} p$ and the Masay french snapbean variety susceptible to $X c p$, resistant to BCMV, anthracnosis and halo blight. Crosses were made by Jim Reiser in 1996, in UNL, Lincoln, NE.
Clay pots of parental lines and 72, $85 \mathrm{~F} 2$ plants from the crosses $\mathrm{Xr} 1 \mathrm{xM}$ Masay and $\mathrm{Xr} 2 \mathrm{xMasay}$, respectively, were grown in 1997, and 40-40 randomly selected F3 families (15 plants per F3 family) were grown in 1998 in the greenhouse of UNL, Lincoln, NE. Five plants were planted in each pot in the F3 experiment. Composition of the potting medium was $15 \%$ soil, $25 \%$ peat, $30 \%$ vermiculite, and $30 \%$ sand. Plants were fertilized once a week with $200 \mathrm{mg} \cdot \mathrm{L}-1$ 20-1020 (NPK) fertilizer. Greenhouse temperatures ranged between $27 \pm 2{ }^{\circ} \mathrm{C}$ to $20 \pm 2{ }^{\circ} \mathrm{C}$ day/night, and the average natural day/night length were about $14 / 10$ hours.

Inoculation. Selection for resistance to $X_{c p}$ was done using two bacterial strains already tested in bean breeding programs of Nebraska or Hungary. The $X_{c p}$ strain EK-11 isolated from common bean in Nebraska was provided by Dr. A.K. Vidaver, Dept. of Plant Pathology, UNL, Lincoln, NE, and strain HUN was provided by János Szarka, Hungary. The strains were cultured on MXP medium for 2-3 days, and then transferred to potassium phosphate buffer $(\mathrm{pH} 7.1)$, with the dilution to read 0.1 on a spectrophotometer at $640 \mathrm{~nm}$, having $108 \mathrm{CFU} / \mathrm{ml}$ final concentration of each strain. The multipleneedle inoculation method (Andrus, 1948; ValladaresSanchez et al., 1979) was used to inoculate the second fully expanded trifoliate leaf of each plant. A potassium phosphate buffered solution was used as a control. The disease reaction on the leaves were recorded 14,17 and 21 days after inoculation. A 1 to 10 leaf reaction rating scale was based on necrosis, water soaking, and yellowed area on the inoculated leaf: 1 is $0-10 \%, 2$ is $11 \%$ to $20 \%, 3$ is $21 \%$ to $30 \%, 4$ is $31 \%$ to $40 \%, 5$ is $41 \%$ to $50 \%, 6$ is $51 \%$ to $60 \%, 7$ is $61 \%$ to $70 \%$, 8 is $71 \%$ to $80 \%, 9$ is $81 \%$ to $90 \%$, and 10 is $91 \%$ to $100 \%$ of the inoculated area with symptoms. Plants scored 1 to 2 were considered resistant, and plants scored 3 to 10 were considered susceptible according to the ratings displayed by the resistant and susceptible parents.

\section{Results and discussion}

High and similar levels of resistance to both $X_{c p}$ strains were expressed by $\mathrm{Xr} 1$ and $\mathrm{Xr} 2$ lines (below $10 \%$ inoculated leaf area with symptoms) (Table 1.). The lines were considered to be homozygous. Masay parent showed high susceptibility to the hungarian isolate (HUN) with almost $100 \%$ leaf area with symptoms. The Nebraskan EK-11 strain caused not so severe symptoms on Masay, although still classifying this variety to be susceptible to the isolate EK-11. There were some overlapping of plants in the parental distributions in case of EK-11, however disease ratings for the strain HUN separated them well. A high percentage of the F2 plants displayed parental genotypes. Frequency distributions suggested rather bimodal then continuous distributions, however clear bimodal distributions for disease reactions were not observed in the crosses (Fig. 1.). The involvement of one major gene, or few genes regulating resistance to $X_{c p}$ in $\mathrm{Xr} 1$ and $\mathrm{Xr} 2$ lines could be concluded. Different hypothetical segregation ratios were analyzed 


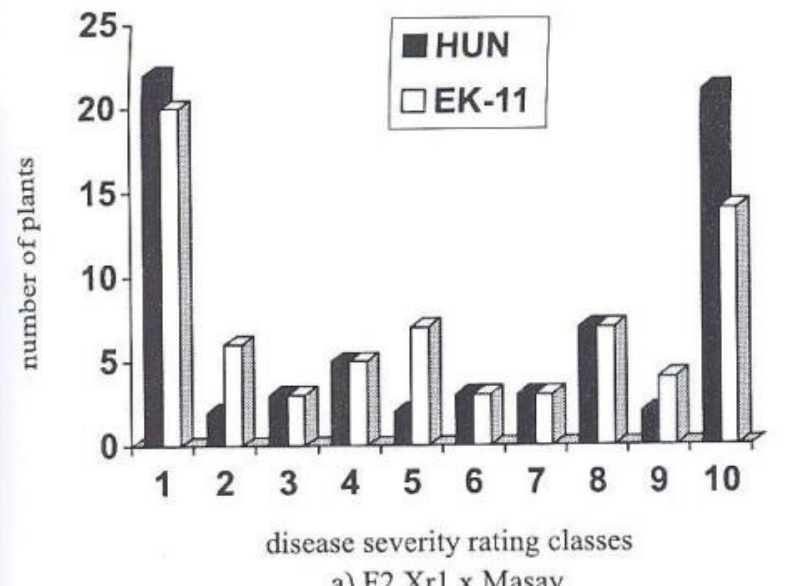

a) F2 Xr1 x Masay

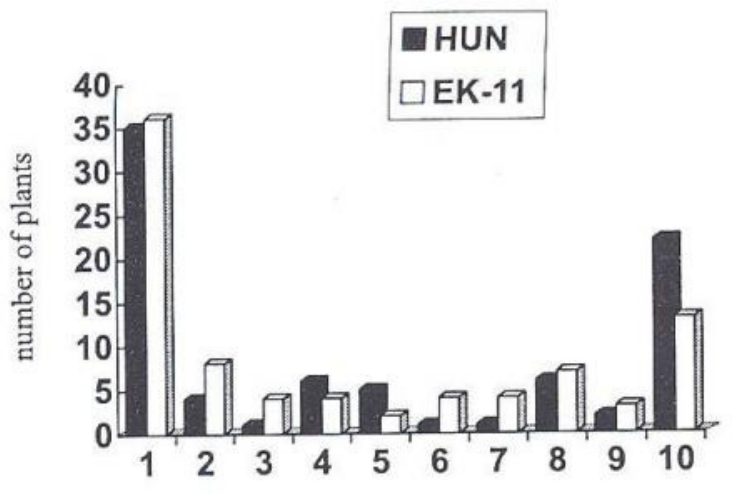

disease severity rating classes

b) F2 Xr2xMasayX

Figure 1 Discase reactions of the F2 populations from the crosses $\mathrm{Xr} 1 \times$ Masay (a) and $\mathrm{Xr} 2 \times$ Masay (b) to the Xcp isolates HUN, and EK-11.

assuming the interaction of few resistance genes (Table 2.). A good fit to a 7:9 ratio of resistant to susceptible plants was observed in both F2 populations, for both $X c p$ isolates, indicating that two complementary recessive genes might be involved in determining resistance to the HUN and EK-11 strains. However, in case of the disease reactions of the F2 progeny from the cross $\mathrm{Xr} 1 \times$ Masay, the resistant to susceptible 1:3 ratio could not be rejected as well. It was hypothesized that resistance to $X c p$ could be determined by only one recessive gene. The hypothesis of one recessive gene for resistance to both $X c p$ strains was confirmed in the $\mathrm{F} 3$ families of crosses derived from $\mathrm{Xr} 1 \mathrm{x}$ Masay and $\mathrm{Xr} 2 \mathrm{x}$

Table 1 Frequency distributions of number of plants, mean values (percentage inoculated leaf area with common blight symptoms) and segregation of plants in F2 progenies for reactions to inoculation with two Xcp strains in $\mathrm{Xrl} x$ Masay and $\mathrm{Xr} 2 \times$ Masay crosses.

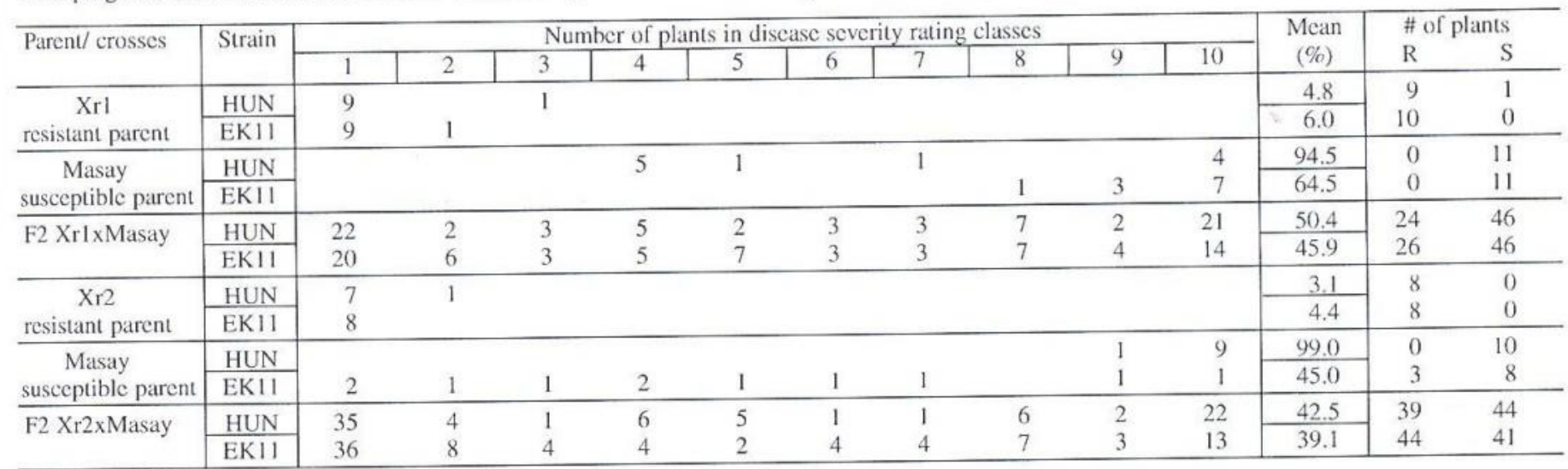

Table 2 Chi-square tests for different segregation ratios of resistant and susceptible plants in the F2 population of crosses between Xr1/Xr2 lines (resistant to $\mathrm{X}(\mathrm{p})$ and Masay (susceptible to $\mathrm{Xcp}$ ) for reactions to two isolates of $\mathrm{Xcp}$.

\begin{tabular}{|c|c|c|c|c|c|c|}
\hline \multirow[b]{2}{*}{ Population } & \multicolumn{6}{|c|}{ Number of plants } \\
\hline & Xcp strain & Observed R:S & Expected R:S & Expected ratio $\mathrm{R}: \mathrm{S}$ & $\chi^{2}$ & $\mathrm{P}$ \\
\hline \multirow[t]{6}{*}{ F2 Xrl x Masay } & HUN & $24: 46$ & $17.5: 52.5$ & $1: 3$ & 3.22 & $0.1-0.05$ \\
\hline & & & $30.6: 39.4$ & $7: 9$ & 2.53 & $0.25-0.1$ \\
\hline & & & $39.4: 30.6$ & $9: 7$ & 13.83 & $<0.001$ \\
\hline & EK-11 & $26: 46$ & $18: 54$ & $1: 3$ & 4.74 & $0.05-0.025$ \\
\hline & & & $31.5: 40.5$ & $7: 9$ & 1.71 & $0.25-0.1$ \\
\hline & & & $40.5: 31.5$ & $9: 7$ & 11.86 & $<0.001$ \\
\hline \multirow[t]{6}{*}{ F2 Xr2 x Masay } & HUN & $39: 44$ & $20.7: 62.3$ & $1: 3$ & 21.8 & $<0.001$ \\
\hline & & & $36: 47$ & $7: 9$ & 0.44 & $0.75-0.5$ \\
\hline & & & $47: 37$ & $9: 7$ & 3.14 & $0.1-0.05$ \\
\hline & EK-11 & $44: 41$ & $21.2: 63.8$ & $1: 3$ & 13.64 & $<0.001$ \\
\hline & & & $37.2: 47.8$ & $7: 9$ & 2.22 & $0.25-0.1$ \\
\hline & & & $47.8: 37.2$ & $9: 7$ & 0.69 & $0.5-0.25$ \\
\hline
\end{tabular}


Masay, based on the goodness of fit to a $1: 2: 1$ ratio of families nonsegregating for resistance, segregating for resistance and susceptibility, and nonsegregating for susceptibility (Table 3.). Segregating families showed resistant phenotype in F2 generation. The segregation pattern of $\mathrm{F} 3$ families indicated that one gene determined the resistance to HUN and EK-11 strains in the cross $\mathrm{Xr} 2 \mathrm{x}$ common bean, and the limited sources of resistance, derived mostly from P. acutifolius. It would be useful to "tag" these genes for resistance to different $X c p$ strains with molecular markers, and to use these markers to increase the level of resistance to $X c p$ by pyramiding the genes present in these lines with other genes for resistance already identified in other $P$. vulgaris germplasm.

Table 3 Chi-square tests for different segregation ratios of F3 families nonsegregating for resistance (all R), segregating for resistance and susceptibility (Seg.), and nonsegregating for susceptibility (all S), derived from the crosses $\mathrm{Xr} 1 \mathrm{x}$ Masay and $\mathrm{Xr} 2 \mathrm{x}$ Masay.

\begin{tabular}{|c|c|c|c|c|c|c|c|}
\hline \multirow[b]{2}{*}{ Population } & \multicolumn{7}{|c|}{ Number of F3 families } \\
\hline & strain & all $\mathrm{R}$ & Seg. & all $\mathrm{S}$ & expected ratios & $\chi^{2}$ & $P$ \\
\hline \multirow[t]{2}{*}{ F3 Xr1 x Masay } & HUN & 7 & 24 & 9 & $\begin{array}{l}1: 2: 1 \\
7: 8: 1 \\
\end{array}$ & $\begin{array}{r}1.35 \\
24.00 \\
\end{array}$ & $\begin{array}{l}0.7-0.5 \\
<0.001\end{array}$ \\
\hline & EK-11 & 12 & 23 & 5 & $\begin{array}{l}1: 2: 1 \\
7: 8: 1 \\
\end{array}$ & $\begin{array}{l}3.35 \\
4.68 \\
\end{array}$ & $\begin{array}{c}0.3-0.1 \\
0.1-0.05 \\
\end{array}$ \\
\hline \multirow[t]{2}{*}{ F3 Xr2 x Masay } & HUN & 14 & 17 & 10 & $\begin{array}{l}1: 2: 1 \\
7: 8: 1\end{array}$ & $\begin{array}{r}1.97 \\
23.08\end{array}$ & $\begin{array}{l}0.5-0.3 \\
<0.001 \\
\end{array}$ \\
\hline & EK-11 & 11 & 24 & 5 & $\begin{array}{l}1: 2: 1 \\
7: 8: 1\end{array}$ & $\begin{array}{l}3.40 \\
5.71\end{array}$ & $\begin{array}{c}0.3-0.1 \\
0.1-0.05\end{array}$ \\
\hline
\end{tabular}

Masay as well, although not in accordance to the results based on its F2 population. This contradiction suggests the presence of some minor, modifying genes beside the monogenic genetic background of resistance, explaining also the lack of clear bimodal distribution of disease reactions in F2 populations. Velich et al. (1994) observed also modifying effects in F1 and F2 progenies of different crosses of $\mathrm{Xr} 1$ and $\mathrm{Xr} 2$ lines, however a dominant monogenic resistance of both lines to the HUN $X c p$ strain was proposed in that study. The value of resistance gene(s) for $\mathrm{CBB}$ in the lines $\mathrm{Xr} 1$ and $\mathrm{Xr} 2$ would be recommended to be investigated in different genetic backgrounds. Beside the dominant resistance genes to $X c p$ found in beans, there are several reports on different systems. A recessive gene for moderately resistance to some strains of $X c p$ was reported by Adams et al., (1988). A single recessive gene determined resistance and two complementary dominant genes determined susceptibility to three $X c p$ isolates has been found in different F2 population of crosses between resistant UNECA common bean mutant and susceptible common bean lines (Dursun, 1994).

Recombinants resistant to only one $X c p$ strain and susceptible to another strain were observed, indicating that different genes controlled the reaction to each $X c p$ strain. The observed segregations of different combinations of reactions to the two $X c p$ strains in both crosses showed coupling linkage between the genes controlling reactions to Xcp (data not shown). Freytag (1989), Dursun (1994), and Park (1998) reported also that three different genes in coupling phase linkage determined resistance to different $X c p$ isolates in tepary bean crosses.

$\mathrm{Xrl}$ and $\mathrm{Xr} 2$ lines represent valuable new monogenic genetic sources in resistance breeding to $\mathrm{CBB}$, also because of the complex genetic background of resistance to $X c p$ in

\section{Acknowledgements}

We are grateful to Dermot P. Coyne for the possibility to perform all the experiments and for his continuous guidance, to A. K. Vidaver and János Szarka for providing us with Xanthomonas campestris pv. phaseoli strains, and to S. O. Park, and L. Sutton for their help during the whole work.

\section{References}

Adams, M. W., Kelly, J. D. \& Seattler, A. W. (1988): A gene for resistance to common blight (Xanthomonas campestris pv. phaseoli). Ann. Rpt. Bean. Improv. Coop. 31: 73-74.

Aggour, A. R. \& Coyne, D. P. (1989): Heritability, phenotypic correlations, and associations of the common blight disease reactions in beans. J. Amer. Soc. Hort. Sci. 114: 828-833.

Andrus, C. F. (1948): A method of testing beans for resistance to bacterial blights. Phytopathology 38: 757-759.

Arnaud-Santana, E., Coyne, D. P., Eskridge, K. M. \& Vidaver, A. K. (1994): Inheritance; low correlations of leaf, pod and seed reactions to common blight disease in common beans; and implications for selection. J. Amer. Soc. Hort. Sci. 119: 116-121.

Ariyarathne, H. M. (1994): Inoculation procedures and heritabilities of the reactions to common bacterial blight in different plant parts in common beans. MS thesis, Univ. of Nebraska, Lincoln, NE, USA.

Békefi Zs. (1997): (Differentiation of bean genotypes, and investigation of development stages with polyacrylamide gel electrophoresis and isoelectro-focusing.) Bab genotipusok elkülönitése és egyedfejlıdési vizsgálatok poliakrilamid gélelektroforézissel és izoelektromos fókuszálással. Diploma diss., Univ. of Horticulture, Budapest, Hungary.

Coyne, D. P. \& Schuster, M. L. (1969): „Tara“ a new great northern dry bean tolerant to common bacterial blight bacterial disease. Univ. of Nebraska, Agr. Expt. Sta. Bul. 506.

Coyne, D. P. \& Schuster, M. L. (1974): Inheritance and linkage relations of reaction to Xanthomonas phaseoli (E.F. Smith) Dowson 
(common blight), stage of plant development and plant habit in Phaseolus vulgaris L. Euphytica 23: 195-204.

Coyne, D. P. \& Schuster, M. L. (1983): Genetics and breeding for resistance to bacterial pathogens in vegetable crops. HortScience 18: $30-36$.

Drijfhout, E. \& Blok, W. J. (1987): Inherintance of resistance to Xanthomonas campestris pv. phaseoli in tepary bean (Phaseolus acutifolius). Euphytica 36: 803-808.

Dursun, A. (1994): Inheritance of resistance to common bacterial blight within Phaseolus vulgaris L. and within Phaseolus acutifolius A. Gray crosses. MS, thesis, Univ, of Nebraska, Lincoln, NE, USA.

Eskridge, K. M. \& Coyne, D. P. (1996): Estimating and testing hypotheses about the number of genes using inbred-backcross data. Heredity 87: 410-412.

Freytag, G. F. (1989): Inheritance of resistance to three strains of common bacterial blight (Xanthomonas campestris) in the cultivated tepary bean (Phaseolus acutifolius var. latifolius). Ann. Rpt. Bean. Improv. Coop. 32: 101-102.

Honma, S. (1956): A bean interspecific hybrid. J. Hered. 47: 217 220.

McElroy, J. B. (1985): Breeding dry beans, Phaseolus vulgaris L., for common bacterial blight resistance derived from Phaseolus acutifolius A. Gray. PhD diss., Cornell Univ., Ithaca, NY.

Mubaga, M. T., Arnaud-Santana, E., Steadman, J. R. \& Coyne, D. P. (1991): Reaction of Pompadour bean lines to Uromyces appendiculatus and Xanthomonas campestris pv. phaseoli. Ann. Rpt. Bean. Improv. Coop. 34: 54-46.

Musaana, M. S., Mwandemele, O. D. \& Kapuya, J. A. (1993): The number of genes controlling resistance in beans to common blight. Ann. Rpt. Bean. Improv. Coop. 36: 156-157.

Opio, A. F., Allen, D. J. \& Teri, J. M. (1996): Pathogenic variation in Xanthomonas campestris pv. phaseoli, the causal agent of common bacterial blight in Phaseolus beans. Plant Pathology 45: 1126-1133.

Park, S. O., Coyne, D. P., Dursun, A. \& Jung, G. (1998): Identifying randomly amplified polymorphic DNA (RAPD) markers linked to major genes for common bacterial blight resistance in tepary bean. J. Amer. Soc. Hort. Sci. 123(2): 278-282.

Rava, C. A., Zimmerman, M. I. \& Romeiro, R. (1987): Inheritance of resistance to Xanthomonas campestris pv. phaseoli (Smith) in Phaseolus vulgaris L. Revista Brasil. Genetica 10,4: 709-727.

Saettler, A. W. 1989: Common bacterial blight, p. 261-283. In:
H.F. Schwarz and M.A. Pastor-Corrales (eds.). Bean production problems in the tropies, Ctr. Intl. Agr. Trop., Cali, Colombia.

Sanders, J. H. \& Schwarz, H. F. (1980): Bean production and pest constraints in Latin America, p. 3-14. In: H. E. Schwarz and G. E. Galvez (eds.). Bean production problems. Centro International de Agricultura Tropical, Cali, Colombia.

Schuster, M. L., Coyne, D. P., Behre, T. \& Leyna, H. (1983): Sources of Phaseolus species resistance and leaf and pod differential reactions to common blight. HortScience 18: 901-903.

Scott, M. E. \& Michaels, T. E. (1988): Inherintance of resistance to common bacterial blight in common bean. Ann. Rpt. Bean. Improv. Coop. 31: 72.

Scott, M. E. \& Michaels, T. E. (1992): Xanthomonas resistance of Phaseolus interspecific cross selections confirmed by field performance. Hort. Science 27: 348-350.

Silva, L. O., Singh, S. P. \& Pastor-Corrales, M. A. (1989): Inheritance of resistance to bacterial blight in common bean. Theor. Appl. Genet. 78: 619-624.

Szarka J. (1993): (Testing new sources of resistance to Xanthomonas campestris pv. phaseoli in bean breeding.) Üj rezisztenciaforrások a Xanthomonas campestris elleni rezisztencianemesítésben. Zöldségterm. Kut. Int. Bull. 25: 75-80.

Yoshii, K., Galvez, G. E. \& Alvarez, G. (1978): Screening bean germplasm for tolerance to common blight caused by Xanthomonas phaseoli and the importance of pathogenic variation to varietal improvement. Plant. Dis. Rpt. 62: 343-347.

Valladares-Sanchez, N. E., Coyne, D. P. \& Schuster, M. L. (1979): Differential reaction of leaves and pods of Phaseolus germplasm to strains of Xanthomenas phaseoli and transgressive segregation for tolerance from crosses of susceptible germplasm. J. Amer. Soc. Hort. Sci. 104: 648-655.

Velich I., Szarka J., Néda P. \& Tóth V. (1991): Diallel analysis of bean to Pseudomonas and Xanthomonas. Ann. Rpt. Bean. Improv. Coop. 35: 31-32.

Velich I., Szarka J. \& Néda P. (1994): Biotic and abiotic stressors in the bean: Genetic background of complex resistance to bacterial diseases. Horticultural Science 26: 49-54

Zaiter, H. Z., Coyne, D. P., Vidaver, A. K. \& Steadman, J. R. (1989): Differential reaction of tepary bean lines to Xanthomonas campestris pv. phaseoli. HortScience 24: 134-137.

Zapata, M. \& Vidaver, A. K. (1987): Differentiation of Xanthomonas campestris pv. phaseoli into pathogenic races based on the tepary bean reactions. Phytopathology 77: 1709 (abstracts). 